\title{
Comparative assessment of 3D reconstruction technique and Cavalieri's principle in predicting the mandibular bone defect volumes
}

\section{Purpose}

The objective of this study was to compare the accuracy of the Cavalieri's principle and $3 \mathrm{D}$ reconstruction in predicting the volume of a bony defect.

\section{Materials and Methods}

Defects of the same approximate size were created on nine artificial mandibles. The actual volume of the defect on each mandible was measured by water displacement, and served as the control. Each mandible was then scanned using a $\mathrm{CBCT}$ and volume measurements were made for each defect using two techniques: Cavalieri's principle and 3D reconstruction. For each defect, the volume obtained by each of the two techniques was compared to the control volume using the analysis of variances (ANOVA) with $p<0.05$.

\section{Results}

ANOVA between the control, 3D reconstruction and Cavalieri's principle groups showed no statistically significant differences $(p=.058)$. When the control group was further analyzed by Dunnett's post-hoc test, the results from Cavalieri's principle were found to be statistically different than the control group $(p=.035)$, whereas the results of $3 D$ reconstruction technique did not reach the level of significance $(p=.523)$.

\section{Conclusion}

Cavalieri's principle significantly underestimates the actual control volume, and is less accurate than the $3 \mathrm{D}$ reconstruction technique. The $3 \mathrm{D}$ reconstruction method is a reliable technique in measuring volume of bony defects.

Keywords: Cone-beam CT; three-dimensional imaging; Cavalieri's principle; defect; image reconstruction

\section{Introduction}

Many surgical advances have been made in the last several decades that have given patients excellent options to regain esthetics and functionality after dentition has been lost. As an example, dental implant therapy has been widely accepted to be a predictable procedure with good long-term results. However, some clinical parameters should be considered prior to surgery, including the quantity of bone surrounding the implant in both vertical and horizontal dimensions (1).

Implant success rates are strongly associated with adequate bone volume, which ensures the placement of dental implants at the correct position and encourages osseointegration (2). Sufficient buccal bone volume around implants is essential, especially for achieving esthetic results in the anterior region $(3,4)$. Following extraction, the remodeling of the alveolar process leads to a predictable pattern of resorption in both the apico-cor-

\author{
Mehmet Ali Altay', \\ Faisal A. Quereshy², \\ Sumit K. Nijhawan', \\ Jose F. Teppa², \\ Michael P. Horan ${ }^{3}$, \\ Nelli Yıldırımyan', \\ Dale A. Baur2 (1)
}

ORCID IDs of the authors: M.A.A. 0000-0001-8886-4783, N.Y. 0000-0001-9860-5494; D.A.B. 0000-0002-5717-9799

\section{'Department of Oral and Maxillofacial Surgery, Akdeniz University Faculty of Dentistry, Antalya, Turkey \\ ${ }^{2}$ Department of Oral and Maxillofacial Surgery, Case Western Reserve University, Faculty of Dental Medicine,} Cleveland, $\mathrm{OH}, \mathrm{USA}$

${ }^{3}$ Oral and Maxillofacial Surgery Section at Cleveland Clinic, Cleveland, $\mathrm{OH}$, USA

This study was presented as poster at the annual meeting of American Association of Oral and Maxillofacial Surgeons held in Honolulu, HI in 2014.

Corresponding Author: Mehmet Ali Altay E-mail: malialtay@hotmail.com

Received: 9 August 2017 Revised: 13 November 2017 Accepted: 12 December 2017

DOI: 10.26650/eor.2018.478 
onal and bucco-lingual dimensions. The presence of buccal bone defects increases the risk of mechanical implant failure $(1,5)$. Pre-prosthetic reconstruction techniques have been proposed to re-establish the anatomic morphology to optimize prosthetic outcome.

Of the various augmentation techniques that have been described for the reconstruction of buccal bone defects, autogenous bone grafting is currently considered the gold standard for alveolar ridge augmentation, although resorption of the graft always remains a concern (6-8). Thorough preoperative planning and evaluation is essential to determine the precise amount of bone graft needed to reconstitute a defect. This will assist in proper selection of the donor site for bone grafting and minimize surgical morbidity.

Cone beam computed tomography (CBCT) is an emerging technology, which provides essential three dimentional (3D) information about the maxillofacial region for preoperative planning. The use of CBCT to quantify the volume of a bony defect in pre-prosthetic surgery can be very useful in determining the quantity of graft to be harvested, which aids in the selection of the appropriate donor site. It has been shown that CBCT technology can accurately measure periodontal defects as well as the depth and diameter of artificially created defects using Cavalieri's principle and volume extrapolation (8-12).

No attempt has been made in the literature to compare different techniques of measuring bony defects using CBCT technology to gauge whether one method provides more accurate measurements. In-Vivo Dental Image Analysis Software (Anatomage Inc, San Jose, CA) has developed a program that approximates the volume of a bony defect, referred to as the $3 \mathrm{D}$ reconstruction tool. An alternative method to measure volume was proposed by Italian mathematician Bonaventura Cavalieri, and is referred to as Cavalieri's principle. Using this principle, the volume of an arbitrary shaped object or defect can be measured by adding the surface area of each slice of the object of interest on a CBCT cross sectional view, and multiplying by the thickness of each slice. Several studies have incorporated this method to measure volume $(8,12-14)$. Fig-

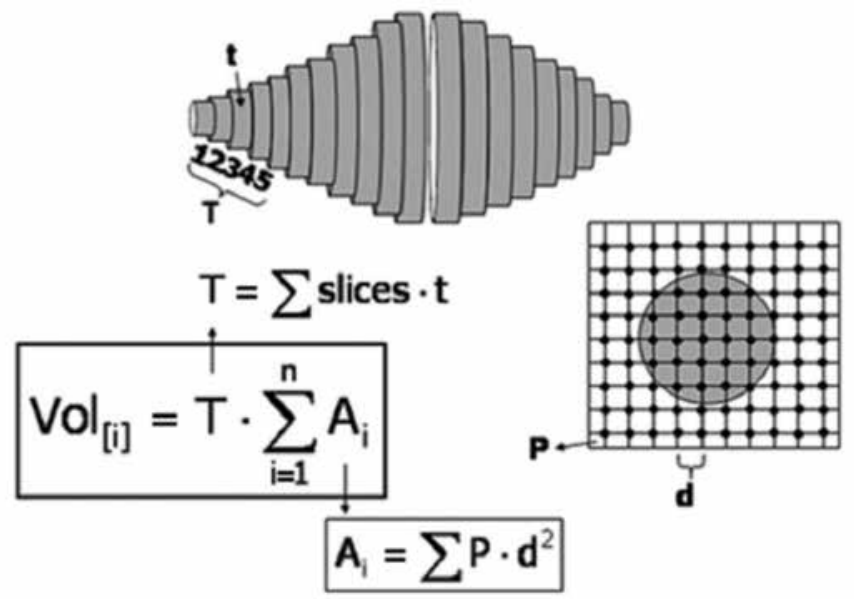

Figure 1. Cavalieri's principle. ( $\Sigma$ cross-sectional area of each slice) $X S$, where $S$ is the thickness of each slice on the $C B C T$, given that $S$ remains constant. (from: Mandarim-de-Lacerda CA. Stereological tools in biomedical research. An Acad Bras Cienc. 2003 Dec;75(4):469-86. Epub 2003 Nov 4). ure 1 demonstrates the method and its application in volume estimation of an organ, a commonly applied stereological method in biomedical research (15).

The purpose of the current study is to compare the 3D reconstruction technique to Cavalieri's principle in regards to measuring the volume of bony defects in the maxillofacial region from $C B C T$ imaging to determine if one method gives a more accurate representation of the actual bony defect. Furthermore, once the most accurate method for measuring volume is elucidated, we assess the degree of inter-user reliability of the technique. In the light of the findings of the present study, it is anticipated to enable clinicians to use CBCT imaging more accurately to predict the volume of defects in the maxillofacial area, which will aid in the planning of maxillo-mandibular surgery.

\section{Materials and methods}

\section{Sample preparation}

Nine artificial, adult-sized, foam cortical shell artificial mandibles (Sawbones; Vashon Island, WA, USA) were obtained. A surgical drill was used to create a geometric defect in the buccal aspect of the alveolus in each of these mandibles (Figure 2a).

A standard rectangular defect of the same size was made in the same location on each artificial mandible. A putty material was molded to fill in the defect for each artificial mandible (Figure 2b).

The putty material was then placed into a graduated cylinder filled with a known volume of distilled water. The amount of water that was displaced after placement of the putty was removed from the graduated cylinder and weighed. Hence, the volume of each defect (in cubic centimeters, which was converted to cubic millimeters) was obtained. This volume was recorded as the control volume for the defect on each artificial mandible.

\section{Image acquisition and $3 D$ reconstruction}

Once the control volume for each mandible was acquired, CBCTs were obtained with CB Mercuray (CB Mercuray; Hitachi Medical Corporation, Tokyo, Japan) at the Craniofacial Imaging Center. Artificial mandibles were positioned in the center of a scanning table with the mandibular plane horizontal and the mid-sagittal plane vertical, and imaging was performed using $15 \mathrm{~mA}, 120, \mathrm{kVp}$, a 4-inch field of view, and resulting in a voxel size of $0.38 \mathrm{~mm}$. All CBCT imaging data were stored in the DICOM (Digital Imaging and Communication) format and then imported to be viewed using InVivo Dental Image Analysis Software. (InVivo Dental Image Analysis Software-Anatomage Inc; San Jose, CA, USA) (Figure 3).

Two techniques were used to measure the volume of bony defects on the artificial mandibles using CBCT (to minimize inter-user error, all measurements were taken by the same individual, who was trained how to obtain measurements using the two techniques, but was blinded to the purpose of the study):

1. The volumetric Reconstruction tool of In Vivo Dental Image Analysis Software was used, as described, to measure the volume of the defect created in each mandible (Figure 4). 

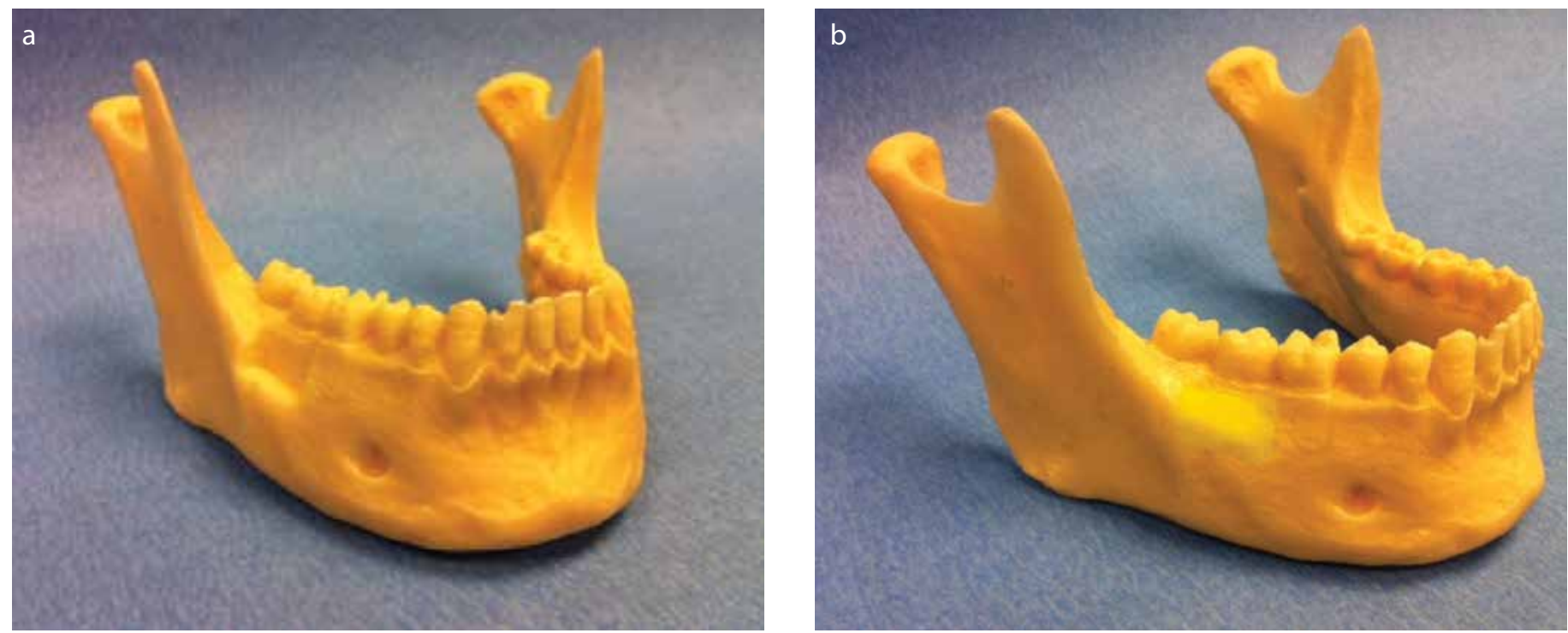

Figure 2. $\boldsymbol{a}, \boldsymbol{b}$. On an artificial mandible, a defect has been created on the buccal alveolar aspect with a bur. The defects were made to be clinically proportional in all mandibles (a). Putty is molded into the defect to reconstitute the volume (b).

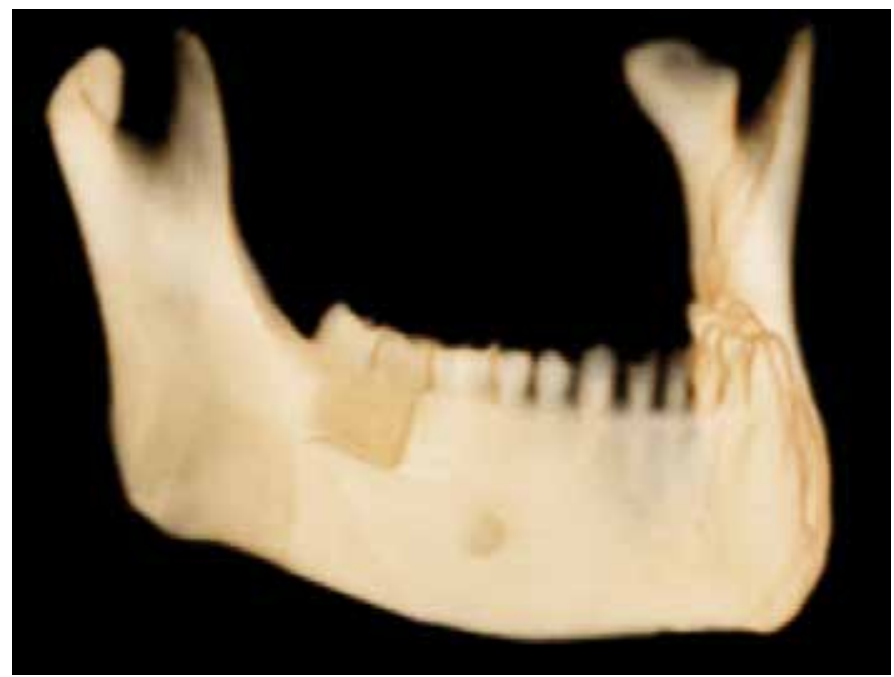

Figure 3. A CBCT image of the defect created in one of the artificial mandibles.

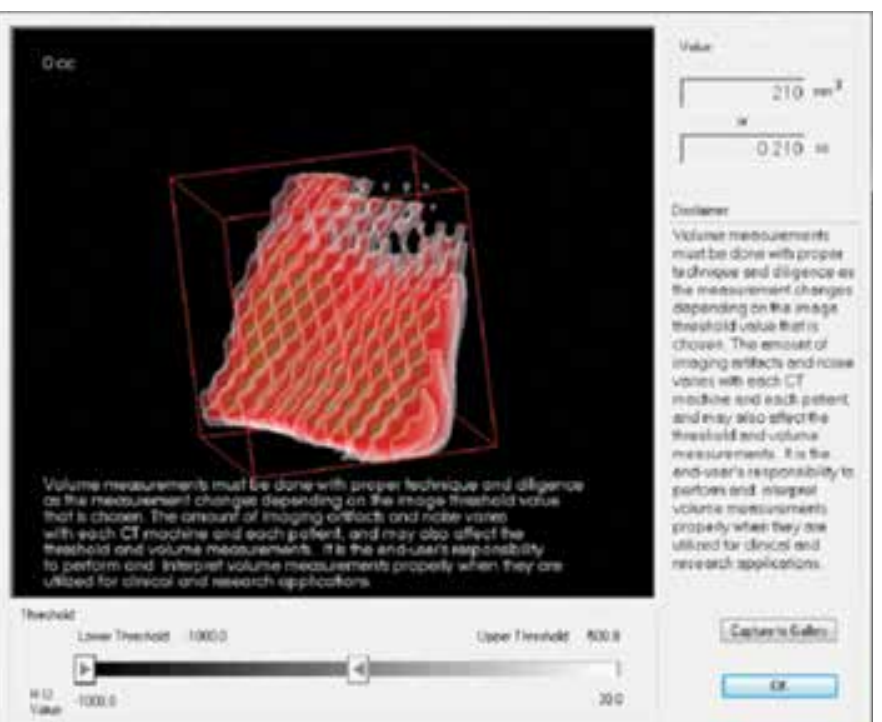

Figure 4. Using the $3 D$ reconstruction method, the defect being isolated. Once the defect has been completely isolated, the image is inverted, leaving only the volume of the defect. The program measures the volume of the isolated defect.

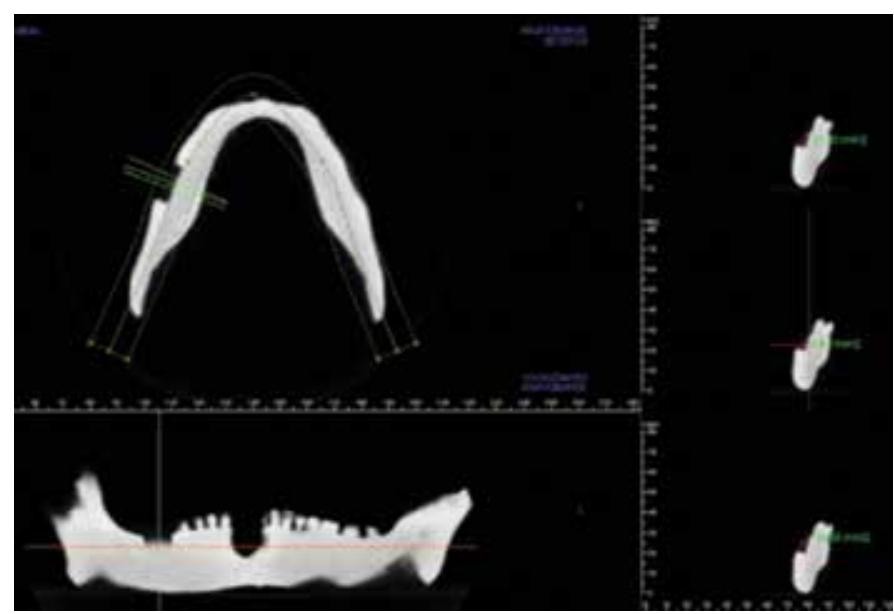

Figure 5. Application of Cavalieri's principle. The cut for each slice is set at $2 \mathrm{~mm}$. At each cross section a geometric measurement tool is used to measure the area in each defect. The sum of the areas is then multiplied by 2 , the total thickness of each slice, to give the volume of the defect.

After the defect was completely isolated, the program was set to measure the defect at -1000 Hounsfield units to -500 Hounsfield units (HU). This was done to ensure the program measured only the volume of defect filled with air, and not any tissue that was not part of the defect (air can be detected at $-1000 \mathrm{HU}$, and tissues start to be detected at $-500 \mathrm{HU})(16)$.

2. Next, the volume of the bony defect in each artificial mandible was measured by using Cavalieri's principle. All imaging was again opened via In Vivo software. The thickness of slices was selected to be $2 \mathrm{~mm}$. A scroll tool was used to navigate through all the sections with the defect on the artificial mandible, and in each slice, the two dimensional cross sectional area of the defect was measured. The areas were added, and multiplied by the thickness of each slice to obtain the measured volume of the bony defect (Figure 5).

Ethics committee approval or informed consent was not required for this study. 


\section{Statistical analysis}

The collected data from all groups were imported to Statistical Package for Social Sciences (SPSS) for Windows software, version 22.0 (SPSS Inc.; Chicago, IL, USA). Normality and homogeneity of the data were tested using Shapiro-Wilk and Levene's tests, respectively. The standard descriptive methods such as the mean and standard deviation were applied to determine the characteristics of the sample. The analysis of variances (ANOVA) was used to determine differences between control, 3D and Cavalieri groups, for which the results were further compared by Dunnett's post-hoc analysis. Data reliability was assessed by an intraclass correlation analysis. The confidence interval was set to $95 \%$ and $p<0.05$ was considered statistically significant.

\begin{tabular}{lccc}
$\begin{array}{l}\text { Table 1. Control, 3D reconstruction and Cavalieri's principle volume } \\
\text { measurements }\end{array}$ & $\begin{array}{c}\text { Control } \\
\text { Volume }\end{array}$ & 3 D & $\begin{array}{c}\text { Cavalieri's } \\
\text { principle }\end{array}$ \\
\hline 1 & $860 \mathrm{~mm}^{3}$ & $790 \mathrm{~mm}^{3}$ & $727.12 \mathrm{~mm}^{3}$ \\
\hline 2 & $1060 \mathrm{~mm}^{3}$ & $866 \mathrm{~mm}^{3}$ & $704.12 \mathrm{~mm}^{3}$ \\
\hline 3 & $1170 \mathrm{~mm}^{3}$ & $1173 \mathrm{~mm}^{3}$ & $896.94 \mathrm{~mm}^{3}$ \\
\hline 4 & $630 \mathrm{~mm}^{3}$ & $601 \mathrm{~mm}^{3}$ & $628 \mathrm{~mm}^{3}$ \\
\hline 5 & $830 \mathrm{~mm}^{3}$ & $769 \mathrm{~mm}^{3}$ & $619.62 \mathrm{~mm}^{3}$ \\
\hline 6 & $830 \mathrm{~mm}^{3}$ & $769 \mathrm{~mm}^{3}$ & $708.32 \mathrm{~mm}^{3}$ \\
\hline 7 & $1140 \mathrm{~mm}^{3}$ & $972 \mathrm{~mm}^{3}$ & $895.12 \mathrm{~mm}^{3}$ \\
\hline 8 & $1130 \mathrm{~mm}^{3}$ & $1160 \mathrm{~mm}^{3}$ & $798.84 \mathrm{~mm}^{3}$ \\
\hline 9 & $1050 \mathrm{~mm}^{3}$ & $902 \mathrm{~mm}^{3}$ & $937.18 \mathrm{~mm}^{3}$ \\
\hline Mean & 966.66 & 889.11 & 768.36 \\
\hline Standard Error & 61.89 & 62.71 & 39.66 \\
\hline Standard Deviation & 185.67 & 188.15 & 118.99 \\
\hline Sample Variance & 34475 & 35403.61 & 14160.87 \\
\hline & & $\mathrm{p}=0.39$ & $\mathrm{p}=0.017$ \\
\hline
\end{tabular}

\section{Results}

It was hypothesized that both methods of volumetric measurement utilizing $\mathrm{CBCT}$ technology would give accurate results, and that there would be no statistical difference between the control volumes and the results obtained by $3 \mathrm{D}$ reconstruction and Cavalieri's principle. Table 1 displays results for control defect volumes in the artificial mandibles as compared to the volume of defects obtained by 3D reconstruction method and Cavalieri's principle. The results showed that at a 95\% confidence interval, there was no statistical difference between the control group and the 3D volumetric reconstruction group. However, Cavalieri's principle underestimates the actual control volume by $21 \%$, an amount determined to be statistically significant $(p<0.05)($ Table 2,3$)$.

\section{Discussion}

The clinical importance of buccal bone volume around implants has been emphasized by several authors (1-5). Defects in the buccal aspect of the alveolar bone are not only unfavorable for the initial planning and placement of implants, but may also jeopardize clinical success when encountered during the maintenance phase. Bony defects in the maxillo-mandibular complex may arise due to several reasons and the reconstruction of these defects commonly requires consideration to a number of factors for ideal prosthetic rehabilitation with dental implants. These factors include the type of graft being considered for reconstruction, patient preferences, morbidity associated with each surgical procedure, and the amount of graft needed to reconstitute a defect. Knowledge of the volume of bony defect can guide pre-prosthetic surgery by helping evaluate which donor site is appropriate for bone grafting if considering an autogenous graft. Hence, an accurate measurement of the defect to be filled can aid tremendously in pre-operative planning and in justification of appropriate surgical grafting procedures. Two-dimensional techniques are regarded as the mainstays for radiologic evaluations of jaws. However, they provide limited information regarding bone morphology, and are not suitable for

95\% Confidence Interval

\begin{tabular}{|c|c|c|c|c|c|c|}
\hline (I) Technique & (J) Technique & Mean Difference (I-J) & Std. Error & Sig. & Lower Bound & Upper Bound \\
\hline $3 D$ & Control & -77.556 & 78.900 & .523 & -262.92 & 107.81 \\
\hline Cavalieri & Control & $-198.304^{*}$ & 78.900 & .035 & -383.67 & -12.94 \\
\hline
\end{tabular}

*The mean difference is significant at the 0.05 level

a Dunnett t-tests treat one group as a control, and compare all other groups against it

Dependent Variable: Volume, Dunnett t (2-sided) ${ }^{\mathrm{a}}$

Lower Bound Upper Bound

$\begin{array}{lccc}\text { Value } & \text { df1 } & \text { df2 } & \text { Sig } \\ 11.741 & 8 & 16 & .000\end{array}$


volumetric assessment of alveolar defects. Though multi-slice CT (MSCT) scan is an established method to assess the bone morphology in implant planning and is commonly regarded as the gold standard, it is associated with 40-60 times more radiation than $\mathrm{CBCT}$ systems that have been introduced more recently. In addition to lower dose of exposure, CBCT systems offer several other advantages over a medical $\mathrm{CT}$, including shorter acquisition times, low cost, and adequate image quality of the mineralized tissues $(17,18)$.

Different studies have utilized various techniques using CBCT to approximate defects, but no study has directly compared these techniques. It was hypothesized in this study that there would be no difference between the control values and the actual measurements obtained for both techniques. No statistical difference was found using only the 3D volumetric reconstruction method. The study showed that, compared to Cavalieri's method of measuring facial bony defects, the 3D reconstruction method was more accurate, although both methods underestimated the actual volume of a maxillofacial defect. One would expect that the mathematically based Cavalieri's principle would be more accurate compared to the $3 \mathrm{D}$ volumetric reconstruction method used, however results from Table 1, show the Cavalieri's principle frequently underestimated the actual volume significantly.

It has been shown that jawbone width measurements on dry mandible using CBCT and spiral tomography are reliable, and on average, they are slightly underestimated; a similar trend was seen in this study (16). Anatomic variations seen in the bone itself can be one possible explanation for the consistent underestimation of volumes using both the $3 \mathrm{D}$ volumetric reconstruction and Cavalieri's principle. Trabecular pattern in bone may be misinterpreted as air rather than part of the osseous anatomy that potentially may lead to exclusion of such spaces in the calculation of bony volumes, leading to an underestimation of volumes (13). Although anatomic variations and trabecular pattern of bone may lead to underestimation of bony volumes, it did not explain the underestimations recorded in this study. In a previous study by Kayipmaz et al. (13), trabecular structure of bone on artificially created "lesion" margins was reported to complicate determination of boundaries of radiographic $C B C T$ sections. In effort to address this issue, defects in this study were created in artificial mandibles that were uniform in internal structure. We believe that the clear internal margins of these defects enabled us to obtain radiographic sections with dimensions similar to those of the actual defects.

Further studies have investigated the dependence of intra-cranial volume (ICV) measurements upon section thickness when using Cavalieri's principle. In a previous study Sahin et al. (19) reported lower ICV values with wider section thicknesses and an underestimation of ICV measurements in planimetry evaluations derived from sections greater than 2 $\mathrm{mm}$ in thickness and recommended selection of thin sections. Conversely, Gadeberg et al. (20) reported overestimation with wider section thickness in MR imaging. Another possible reason for the inaccuracy encountered with Cavalieri's principle in the present study is the assumption that the area of each section measured is the same throughout the $2 \mathrm{~mm}$ slice, and this may not be the case. It should, however, be noted that utilizing a section thickness of $2 \mathrm{~mm}$ in the present study rep- resents a technique that is reproducible and applicable in the dental office setting, which would otherwise remain impracticable if thinner sections were used.

After comparing the different techniques to actual control volumes, we believe $C B C T$ s remain useful in predicting the volume of bony defect, especially using the $3 \mathrm{D}$ reconstruction method, which was found to be a valid and precise method of volume approximation. This study suggests that Cavalieri's principle is less accurate than $3 \mathrm{D}$ reconstruction in determining the volume of bony defects, although other studies have successfully used this principle to give an accurate representation of volume (Table 2$)(8,12-14)$. In a previous study by Smolka et al. (8), volumetric measurements of calvarial bone grafts were successfully performed using software based on Cavalieri's principle. Pinsky et al. (12) applied a similar technique for determining osseous defect sizes using 3D CBCT and suggested that clinically acceptable accuracy can be obtained with such a technique when performing volumetric analysis of small osseous defects of the human mandible. Moreover, Cavalieri's principle was also used in several other medical fields to assess the volume of lesions or to evaluate the regression of tumors after chemo-radiotherapy $(21,22)$.

The lack of soft tissue simulation and the relatively small sample size are among the main limitations of this study that need to be taken into consideration when interpreting its findings. Further studies with qualified simulation of both hard and soft tissues on larger sample sizes may provide clinicians with a better understanding of the comparative evaluation of these two techniques. Additionally, Hounsfield's scale, the validity of which remains an issue of debate in CBCT was used in the present study. Although controversial, the authors of the study believe that there is sufficient evidence in the current literature supporting the use of HUs in dentistry, which conveniently provide an insight to the mineral density of the hard tissues of the maxillofacial complex $(23,24)$.

\section{Conclusion}

This study did not reveal statistically significant difference in volumetric analysis performed with $3 \mathrm{D} \mathrm{CBCT}$ reconstruction and the control values, whereas statistically significant underestimation was observed with the method based on Cavalieri's principle. When our findings are evaluated in consideration of contradictory findings reported in a limited number of previous studies, we believe that further research is required to determine the true efficacy of the techniques applied in this study.

Ethics Committee Approval: Ethics committee approval was not required for this study.

\section{Informed Consent: Not required.}

Peer-review: Externally peer-reviewed.

Author Contributions: DAB designed the study. SKN, JFT and MPH generated and gathered the data. MAA, FAQ, SKN, JFT and MPH analyzed the data. MAA, FAQ and NY wrote the majority of the original draft. All authors approved the final version of the paper. 
Conflict of Interest: The authors have no conflicts of interest to declare.

Financial Disclosure: Dr. Altay has provided consultancy for Checkpoint Surgical LLC. in 2014, and Dr. Baur is a paid consultant for Novartis Pharmaceuticals and Checkpoint Surgical LLC. Other authors declare that they have no competing financial interests.

Türkçe öz: Alt çene kemiğindeki defektlerin hacimlerinin ölçülmesi amacıyla kullanılan 3 boyutlu rekonstruksiyon ve Cavalieri yöntemlerinin karşılaştırmalı olarak değerlendirilmesi. Amaç: Bu çalışmanın amacı kemik defektlerinin hacimsel tahmininde Cavalieri prensibi ve 3 boyutlu rekonstrüksiyon tekniğinin doğruluklarının karşılaştırılmasıdır. Gereç ve Yöntem: Dokuz adet yapay mandibula üzerinde yaklaşık olarak aynı boyutlarda defektler oluşturulmuştur. Her mandibulaki defektin gerçek hacmi suyun yer değiştirmesi ile ölçülmüş ve kontrol grubu olarak belirlenmiştir. Ardından, her mandibula konik ışınlı bilgisayarlı tomografi (cone-beam computed tomography - CBCT) ile taranmış ve defektlerin hacimsel ölçümleri iki teknik kullanılarak yapılmıştır: Cavalieri prensibi ve 3 boyutlu rekonstrüksiyon. Defektlerin her iki teknikle elde edilen hacimsel ölçümleri, kontrol hacimleri ile karşılaştırılmış ve istatistiksel anlamlılık düzeyi $p<0.05$ olacak şekilde varyans analizi ile (ANOVA) değerlendirilmiştir. Bulgular: Kontrol, 3 boyutlu rekonstrüksiyon ve Cavalieri'nin prensibi gruplarının ANOVA ile değerlendirilmesi sonucunda gruplar arasında istatistiksel olarak anlamlı bir farklılık bulunamamıştır ( $p=.058$ ). Kontrol grubu Dunnett'in post-hoc testi ile ileri analize tabi tutulduğunda, Cavalieri'nin prensibi ile yapılan ölçümlerin kontrole klyasla anlamlı farklılık gösterdiği ( $p=.035)$; ancak 3 boyutlu rekonstrüksiyon tekniğinin anlamlılık seviyesine ulaşmadığı görülmüştür ( $p=.523$ ). Sonuç: Cavalieri prensibi, kontrol hacminin olması gerekenden daha az ölçülmesine neden olmaktadır. Bu prensibinin doğruluğu, 3 boyutlu rekonstrüksiyon tekniğine göre daha düşüktür. Üç boyutlu rekonstrüksiyon metodu, kemik defektlerinin hacimsel ölçümünde daha güvenilir bir tekniktir. Anahtar kelimeler: Konik ışınlı bilgisayarlı tomografi; üç boyutlu görüntüleme; Cavalieri prensibi; defekt; görüntü rekonstrüksiyonu

\section{References}

1. Shiratori LN, Marotti J, Yamanouchi J, Chilvarquer I, Contin I, Tortamano-Neto P. Measurement of buccal bone volume of dental implants by means of cone-beam computed tomography. Clin Oral Implants Res 2012; 23: 797-804. [CrossRef]

2. Spin-Neto R, Stavropoulos A, Dias Pereira LA, Marcantonio E Jr, Wenzel A. Fate of autologous and fresh-frozen allogeneic block bone grafts used for ridge augmentation. A CBCT-based analysis. Clin Oral Implants Res 2013; 24: 167-73. [CrossRef]

3. Araujo MG, Sukekava F, Wennström JL, Lindhe J. Tissue modeling following implant placement in fresh extraction sockets. Clin Oral Implants Res 2006; 17: 615-24. [CrossRef]

4. Grütter L, Belser UC. Implant loading protocols for the partially edentulous esthetic zone. Int J Oral Maxillofac Implants 2009; 24: 169-79.

5. Van Oosterwyck H, Duyck J, Vander Sloten J, Van Der Perre G, Naert I. Peri-implant bone tissue strains in cases of dehiscence: a finite element study. Clin Oral Implants Res 2002; 13: 327-33. [CrossRef]

6. Louis, PJ. Bone Grafting the Mandible. Den Clin N Am 2011; 55: 673-95. [CrossRef]

7. Quereshy FA, Dhaliwal HS, El SA, Horan MP, Dhaliwal SS. Resorbable screw fixation for cortical onlay bone grafting: a pilot study with preliminary results. J Oral Maxillofac Surg 2010; 68: 2497502. [CrossRef]

8. Smolka W, Eggensperger N, Carollo V, Ozdoba C, lizuka T. Changes in the volume and density of calvarial split bone grafts after alveolar ridge augmentation. Clin Oral Implants Res 2006; 17: 149-55. [CrossRef]

9. Agbaje JO, Jacobs R, Maes F, Michiels K, van Steenberghe D. Volumetric analysis of extraction sockets using cone beam computed tomography: a pilot study on ex vivo jaw bone. J Clin Periodontol 2007; 34: 985-90. [CrossRef]

10. Quereshy FA, Barnum G, Demko C, Horan M, Palomo JM, Baur DA, Jannuzzi J. Use of cone beam computed tomography to volumetrically assess alveolar cleft defects-preliminary results. J Oral Maxillofac Surg 2012; 70: 188-91. [CrossRef]

11. Leung CC, Palomo L, Griffith R, Hans MG. Accuracy and reliability of cone-beam computed tomography for measuring alveolar bone height and detecting bony dehiscences and fenestrations. Am J Orthod Dentofacial Orthop 2010; 137: 109-19. [CrossRef]

12. Pinsky HM, Dyda S, Pinsky RW, Misch KA, Sarment DP. Accuracy of three-dimensional measurements using cone-beam CT. Dentomaxillofac Radiol 2006; 35: 410-6. [CrossRef]

13. Kayipmaz S, Sezgin OS, Saricaoglu ST, Bas O, Sahin B, Küçük M. The estimation of the volume of sheep mandibular defects using cone-beam computed tomography images and a stereological method. Dentomaxillofac Radiol 2011; 40: 165-9. [CrossRef]

14. Michel RP, Cruz-Orive LM. Application of the Cavalieri Principle and vertical sections method to lung: estimation of volume and pleural surface area. Journal of Microscopy 1988; 150: 117-36. [CrossRef]

15. Mandarim-de-Lacerda CA. Stereological tools in biomedical research. An Acad Bras Cienc 2003; 75: 469-86. [CrossRef]

16. Chowdhury B, Sjöström L, Alpsten M, Kostanty J, Kvist H, Löfgren R. A multicompartment body composition technique based on computerized tomography. Int J Obes Relat Metab Disord 1994; 18: 219-34

17. Draenert FG, Gebhart F, Berthold M, Gosau M, Wagner W. Evaluation of demineralized bone and bone transplants in vitro and in vivo with cone beam computed tomography imaging. Dentomaxillofac Radiol 2010; 39: 264-9. [CrossRef]

18. Nackaerts O, Maes F, Yan H, Couto Souza P, Pauwels R, Jacobs R. Analysis of intensity variability in multislice and cone beam computed tomography. Clin Oral Implants Res 2011; 22: 873-9. [CrossRef]

19. Sahin B, Acer N, Sonmez OF, Emirzeoglu M, Basaloglu H, Uzun A, Bilgic S. Comparison of four methods for the estimation of intracranial volume: a gold standard study. Clin Anat 2007; 20: 766-73. [CrossRef]

20. Gadeberg P, Gundersen HJ, Tågehøj F. How accurate are measurements on MRI? A study on multiple sclerosis using reliable 3D stereological methods. J Magn Reson Imaging 1999; 10: 729. [CrossRef]

21. Abreu LADS, Damasceno-Ferreira JA, Monteiro ME, Pereira-Sampaio MA, Sampaio FJB, de Souza DB. Volume and shape assessment of renal radiofrequency ablation lesion. Urology 2018; 116: 229. [CrossRef]

22. Bingol F, Yoruk O, Bingol BO, Erdemci B, Ozkan O, Mazlumoglu MR. Estimation of the efficacy of chemo-radiotherapy on tumor regression in the patients with laryngeal cancer via computerized tomography using the Cavalieri method. Acta Otolaryngol 2016; 136: 164-7. [CrossRef]

23. Parsa A, Ibrahim N, Hassan B, Motroni A, van der Stelt P, Wismeijer D. Reliability of voxel gray values in cone beam computed tomography for preoperative implant planning assessment. Int J Oral Maxillofac Implants 2012; 27: 1438-42.

24. Nomura $Y$, Watanabe $H$, Honda $E$, Kurabayashi T. Reliability of voxel values from cone-beam computed tomography for dental use in evaluating bone mineral density. Clin Oral Implants Res 2010; 21: 558-62.v 